\title{
Diabetes mellitus in a young Amazon Indian child
}

\author{
Diabetes Center, Universidade Federal de São Paulo - Escola Paulista de \\ Medicina, São Paulo, Brazil
}

- Mônica Andrade Lima Gabbay

- Edson Bussad

- Ligia Persoli

- Walkiria Volpini

- Sérgio Atala Dib
INTRロDUCTIロN

Type 1 diabetes mellitus (T1DM) is still considered to be the commoner form of diabetes mellitus in young people. However, T1DM has not been reported in the literature in any child or adolescent known to have full American Indian heritage. None of the probable case subjects with type 1 diabetes described in a recent study ${ }^{1}$ population were known to be of full American Indian heritage ${ }^{2}$.

We have recently reported ${ }^{3}$ on latent autoimmune diabetes of the adult (LADA) in a Xavante-Jê Indian from the western groups of the Sangradouro community in Poxoréu, State of Mato Grosso, Brazil. Here, we show the first case of diabetes in a South American Indian child from the Yanomami reserve in the tropical rainforest of northern Brazil and southern Venezuela.

CASE REPQRT

A 6-year-old Yanomami Indian girl was referred to the Diabetes Center of Universidade Federal de São Paulo (Unifesp) to control her diabetes. This disease was diagnosed at the age of two years, during treatment for a tuberculosis infection. At that time, she developed fatigue, thirst, polyuria, weight loss and fasting blood glucose (FBG) of $480 \mathrm{mg} / \mathrm{dl}$. Following this, she was given the recommendation to have a daily shot of insulin ( 0.5 units $/ \mathrm{kg}$ of body weight), but her family refused to give her the shots, and so this therapy became irregular. Over the last three years, she has presented three diabetic ketoacidosis crises. She is the ninth daughter of short-stature parents. There is no history of diabetes mellitus in her family.

When she was first seen at the Diabetes Center, her physical examination was normal, despite her height of only $92 \mathrm{~cm}$ (-3.7 standard deviations, SD) and weight of only $12.1 \mathrm{~kg}$ $(-2.1 \mathrm{SD})$. She had FBG of $510 \mathrm{mg} / \mathrm{dl}$, nega- tive ketonuria, HbA1c [glycated haemoglobin of $7.8 \%$ (normal value, nv: $2.5-5.5 \%$ ), normal albuminuria and normal retinal examination. Autoantibodies directed against glutamic acid decarboxylase (GAD-65) and tyrosine phosphatase-related enzyme proteins (ICA512/IA2) were measured using quantitative radiobinding assays. Anti-GAD65 was negative on two different occasions (GAD 65Ab index: 0.21 and $-0.02 \mathrm{U} ; \mathrm{nv}<0.22 \mathrm{U}$ ) and the ICA512/IA2 $\mathrm{Ab}$ index was $3.71 \mathrm{U} / \mathrm{ml}(\mathrm{nv}<0.97 \mathrm{U} / \mathrm{ml})$. At this time, the patient's fasting serum C-peptide (FCP) level, measured by radioimmunoassay, was $0.64 \mathrm{pmol} / \mathrm{ml}$ (nv: 0.11-1.2 $\mathrm{pmol} / \mathrm{ml}$ ). Her human leukocyte antigen (HLA) typing showed DRB $1^{*} 0411$, DQA $1^{*} 0303$, DQB $1 * 0302 / \mathrm{DRB} 1 * 14$, DQA $1{ }^{*} 0503$ and DQB $1 * 0307$. These haplotypes were identical to those of her parents.

Over a two-week period, while her parents were attending a diabetes education program, her glycemic levels became normalized by means of human pre-mixture $(80 \mathrm{~N} / 20 \mathrm{R})$ insulin before breakfast and supper (0.9 units $/ \mathrm{kg} /$ day). She then went back home to the Yanomami Indian reserve.

DISCUSSION

There are twelve thousand Yanomami Indians alive today ${ }^{4}$, in about 230 villages, with a population of around 150-200 individuals in each village (95\% of them inside the Amazon forest and the others along the major rivers). ${ }^{4}$ They have had contact with the civilized world only over the last 20 years. ${ }^{4}$ Their diet (sweet potatoes, vegetables and bananas) is monotonous. Their most common illnesses are malaria, infectious diarrhea and acute respiratory diseases. ${ }^{4}$

Bloch et al., studying an Indian adult population from this group, found higher mean capillary blood glucose among women than among men, although still within the

\section{ABSTRACT}

CONTEXT: Although type 2 diabetes has been described among American Indian children, no case of type 1 diabetes has been reported in the literature.

CASE REPORT: We report the first case of diabetes in a South American Indian child from the tropical rainforest, who was positive for IA2 autoantibodies and genetic markers of susceptibility to type 1 diabetes, but also demonstrated residual beta cell function four years after diagnosis.

KEY WORDS: Diabetes Mellitus. Ethnic Groups. HLA antigens. South american indians. Autoantibodies. C-peptide. 
normal range. These blood glucose levels correlated with the body mass index and waist-to-hip circumference ratio. ${ }^{5}$

The diabetic Yanomami child reported on here expressed the DRB1*04-DQB1*0302 haplotype that is associated with susceptibility to type 1 diabetes in Caucasians and also in our mixed Brazilian population. ${ }^{6}$ Furthermore, we found a great diversity of DRB $1 * 04$ alleles in Brazilian families with type 1 diabetes in our previous study.

Her FCP $(0.64 \mathrm{pmol} / \mathrm{ml})$ was higher than the Diabetes Control and Complication Trial (DCCT) criterion (less than $0.2 \mathrm{pmol} /$ $\mathrm{ml})$ to insulin-dependent diabetes mellitus (IDDM). ${ }^{7}$ This FCP level suggests that she still had residual beta cell function four years after the clinical diagnosis. The absence of GAD65 antibodies in this girl could be due to antibodies becoming seronegative during disease evolution or it could suggest Type $1 \mathrm{~B}$ diabetes. It is interesting that, some years ago, we reported ${ }^{8}$ on a case of young Indian man from another group (Krenak-Macro-Jê) whose diabetes was diagnosed by means of spontaneous ketoacidosis, but who did not have autoantibodies (anti-insulin and islet beta cells) and had a normal FCP $(0.95 \mathrm{pmol} / \mathrm{ml})$. Therefore, both cases could be classified initially as atypical diabetes. Recently, the meta- bolic and immunological features of Chinese patients with atypical diabetes mellitus has also been described. ${ }^{?}$

Idiopathic type 1 diabetes, by definition, has no known etiology. Individuals with this form of diabetes can have heterogeneous clinical manifestations. In African-American patients, it has been called atypical diabetes or flatbush diabetes. These individuals can have diabetic ketoacidosis as their initial clinical presentation, but autoimmune islet cell markers are absent at diagnosis and they have physical characteristics similar to type 2 diabetes patients. ${ }^{10}$

Asian idiopathic type 1 diabetes cases have different features. Urakami et al. ${ }^{11}$ reported, among 85 Japanese children with type 1 diabetes, that $16.5 \%$ had a new subtype of type 1 diabetes that was characterized by fulminant onset, absolute insulin deficiency and absence of beta-cell autoimmunity markers. These patients had high-risk HLA typing (either HLA-DR4 or DR9) and low or undetectable serum C-peptide values.

Harwell et al., ${ }^{12}$ studying a young American Indian population (aged $<20$ years) from Montana and Wyoming (United States), considered that children with diabetes had type 1 diabetes if aged $\leq 5$ years, with weight-for-age lower than the $15^{\text {th }}$ percentile at diagnosis or positive results from islet cell antibody tests less than one year after diagnosis. They considered children to have probable type 2 diabetes if their weight-for-age was $\geq 85^{\text {th }}$ percentile, acanthosis nigricans was noted, serum C-peptide or insulin was high within one year of diagnosis, there was a family history of type 2 diabetes, oral hypoglycemic agents with or without insulin were used at follow-up more than one year after diagnosis, or there was no current pharmacological treatment one year after diagnosis.

In accordance with these criteria our diabetic Indian child had the characteristics of type 1 (age less than 5 years at diagnosis, low body weight, positive for IA 2 antibodies, genetic markers for type 1 diabetes and in need of insulin treatment since diagnosis). Nonetheless, she still had residual endogenous insulin secretion, as shown by FCP levels.

In summary, this Amazon Indian emphasizes the difficulty in accurately classifying diabetes by type among young people from the same ethnic groups.

Population-based studies that characterize both residual beta-cell function and multiple autoimmune antibodies serially are needed to define the natural history of diabetes and clarify the potential heterogeneity of the disease in young Indian populations.
1. Harwell TS, McDowall JM, Moore K, Fagot-Campagna A, Helgerson SD, Gohdes D. Establishing surveillance for diabetes in American Indian youth. Diabetes Care. 2001;24(6):1029-32.

2. Maturity-onset diabetes in young black Americans. N Engl J Med. 1987;317(6):380-2

3. Vieira Filho JP, Moisés RC, de Sá JR, Chacra AR, Dib SA. Laten autoimmune diabetes of the adult (LADA) in a Brazilian Indian. Sao Paulo Med J. 2001;119(2):84-5.

4.Albert B. Yanomami. Available from URL: http://www.socioambiental.org/pib/epi/yanomami/print.htm. Accessed in 2005 (Mar 02).

5. Bloch KV, Coutinho ESF, Lôbo MSC, Oliveira JEP, Milech A. Pressão arterial, glicemia capilar e medidas antropométricas em uma população yanomámi. [Blood pressure, capillary glucose, and anthropometric measurements in a yanomámi population. Cad Saúde Pública. 1993;9(4):428-38.
6. Volpini WM, Testa GV, Marques SB, et al. Family-based association of HLA class II alleles and haplotypes with type I diabetes in Brazilians reveals some characteristics of a highly diversified population. Human Immunol. 2001;62(11):1226-33.

7. The Diabetes Control and Complications Trial (DCCT). Design and methodologic considerations for the feasibility phase. The DCCT Research Group. Diabetes. 1986;35(5):530-45.

8. Vieira Filho JPB, Aguadé LCM, Augusto SS, Sá JR, Dib SA. Cetoacidose diabética em índio Krenak. [Ketoacidosis diabetic in Krenak indian]. Rev Assoc Med Bras. 1992;38(1):28-30.

9. Tan KC, Mackay IR, Zimmet PZ, Hawkins BR, Lam KS. Metabolic and immunologic features of Chinese patients with atypical diabetes mellitus. Diabetes Care. 2000;23(3):335-8.

10. Piñero-Piloña A, Litonjua P, Aviles-Santa L, Reskin P. Idiopathic type 1 diabetes in Dallas, Texas: a 5-year experience. Diabetes Care. 2001;24(6):1014-8.
REFERENCES

110. Urakami T, Nakagawa M, Morimoto S, Kubota S, Owada M, Harada K. A subtype of markedly abrupt onset with absolute insulin deficiency in idiopathic type 1 diabetes in Japanese children. Diabetes Care. 2002;25(12):2353-4.

12. Harwell TS, McDowall JM, Moore K, Fagot-Campagna A, Helgerson SD, Gohdes D. Establishing surveillance for diabetes in American Indian youth. Diabetes Care. 2001;24(6):1029- 32.

Sources of Funding: Not declared Conflicts of interest: None Date of first submission: June 3, 2004
Last received: March 3, 2005

Accepted: March 4, 2005 


\section{AUTHOR INFIRMATION}

Mônica Andrade Lima Gabbay, MD, MSc. Diabetes Center, Universidade Federal de São Paulo - Escola Paulista de Medicina, São Paulo, Brazil.

Edson Bussad, MD. Universidade Federal de Roraima, Roraima, Brazil.

Ligia Persoli, MD, PhD. Histocompatibility Laboratory, Hemotherapy Center, Universidade de Campinas, Campinas, São Paulo, Brazil.

Walkiria Volpini MD, PhD. Histocompatibility Laboratory, Hemotherapy Center, Universidade de Campinas, Campinas, São Paulo, Brazil

Sergio Atala Dib, MD, PhD. Diabetes Center, Universidade Federal de São Paulo - Escola Paulista de Medicina, São Paulo, Brazil.

\section{Address for correspondence:}

Sergio Atala Dib

Disciplina de Endocrinologia, Universidade Federal

de São Paulo

Rua Botucatu, 740 - 2o andar

São Paulo (SP) - Brasil - CEP 04034-970

Tel. (+55 11) 5576-4235 - (+55 11) 5571-9826

Email: sadib@endocrino.epm.br

\section{Diabetes Melliłus em uma criança indígena do Amazonas}

CONTEXTO: $O$ diabetes mellitus tipo 2 tem sido descrito em populações indígenas, mas casos de diabetes mellitus tipo 1 são raros e muitas vezes não bem caracterizados, devido às condições inerentes ao meio em que habitam os índios.

RELATO DE CASO: Nós relatamos aqui o primeiro caso de diabetes do tipo 1 em uma criança indígena da América do Sul, proveniente da floresta Amazônica, caracterizado por marcadores genéticos, imunológicos e clínicos, mas que apresentava função residual das células beta após quatro anos do diagnóstico, o que pode dificultar, às vezes, a caracterização clínica do tipo especifico de diabetes em algumas populações.

PALAVRAS-CHAVE: Diabetes Mellitus. Índio. Antígenos HLA. Auto-anticorpos. Peptídeo C. Grupos étnicos. Índios sul-americanos. 